\title{
Evolutionary scenarios for the origin of an Antarctic tardigrade species based on molecular clock analyses and biogeographic data
}

\author{
Roberto Guidetti ${ }^{1,4}$, Sandra J. McInnes ${ }^{2}$, Michele Cesari ${ }^{1}$, Lorena Rebecchi ${ }^{1}$, Omar Rota-Stabelli ${ }^{3}$ \\ ${ }^{1}$ Department of Life Sciences, University of Modena and Reggio Emilia, Via Campi 213/D, Modena, 41125, Italy \\ ${ }^{2}$ British Antarctic Survey, Natural Environment Research Council, High Cross, Madingley Road, Cambridge, CB3 \\ OET, UK \\ ${ }^{3}$ Research and Innovation Centre, Fondazione Edmund Mach, via Mach 1, San Michele all'Adige, Trento, 38010, \\ Italy \\ ${ }^{4}$ E-mail: roberto.guidetti@unimore.it
}

Key words: Gondwana, historical biogeography, Last Glacial Maximum, molecular clock dating, vicariance

\begin{abstract}
The origin of the Antarctic continental extant fauna is a highly debated topic, complicated by the paucity of organisms for which we have clear biogeographic distributions and understanding of their evolutionary timescale. To shed new light on this topic, we coupled molecular clock analyses with biogeographic studies on the heterotardigrade genus Mopsechiniscus. This taxon includes species with endemic distributions in Antarctica and other regions of the southern hemisphere. Molecular dating using different models and calibration priors retrieved similar divergence time for the split between the Antarctic and South American Mopsechiniscus lineages (32-48 Mya) and the estimated age of the Drake Passage opening that led to the separation of Antarctica and South America. Our divergence estimates are congruent with other independent studies in dating Gondwanan geological events. Although different analyses retrieved similar results for the internal relationships within the Heterotardigrada, our results indicated that the molecular dating of tardigrades using genes coding for ribosomal RNA (18S and $28 \mathrm{~S}$ rDNA) is a complex task, revealed by a very wide range of posterior density and a relative difficulty in discriminating between competing models. Overall, our study indicates that Mopsechiniscus is an ancient genus with a clear Gondwanan distribution, in which speciation was probably directed by a cooccurrence of vicariance and glacial events.
\end{abstract}

\section{Contents}

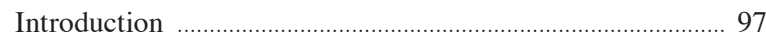

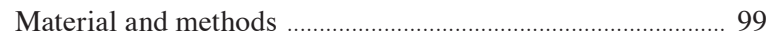

Results and discussion .......................................................... 101

Molecular clock analyses ................................................... 101

Test of model fit ........................................................... 101

Molecular dating .............................................................. 101

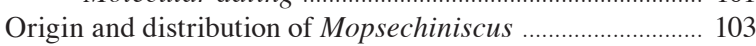

Biogeographical distribution and ecology of

Mopsechiniscus species ................................................. 103

Mopsechiniscus in Antarctica .............................................. 105

Mopsechiniscus in the sub-Antarctic islands ................ 107

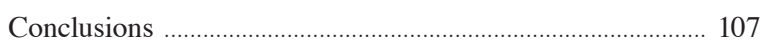

Acknowledgements ................................................................ 108

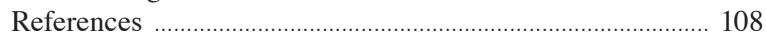

\section{Introduction}

The biogeographic origins of the extant limno-terrestrial fauna of maritime and continental Antarctica, and the sub-Antarctic islands have been debated for more than a decade (e.g. Pugh and Scott, 2002; Barnes et al., 2006; Convey et al., 2007, 2008; Pugh and Convey, 2008; Convey, 2010; Vyverman et al., 2010; Fraser et al., 2012). The current biogeographic distributions of Antarctic endemic or circum-Antarctic taxa could be the result of recent, ongoing dispersal in Antarctic regions (re-colonisation hypothesis; see Pugh, 2004) and/ or the consequence of relict Gondwanan taxa surviving the extreme, harsh conditions of Antarctica over the last 23 million years (My) (glacial refugia hypothesis; see Stevens et al., 2006). In the latter case, the extant fauna would be represented by ancient endemic taxa or new more recent taxa that evolved in situ from populations that had survived in ice-free refugia.

Antarctica formed a major component of the Gondwanan continent with a rich fauna and flora before geological and climate evolution isolated the continent and successive ice ages eliminated most plant and animal life. The extant biota that might have been associated with that period has been restricted to cryptogams and terrestrial meiofauna (Convey, 2010). Tardigrades, rotifers, and nematodes are major components of terrestrial Antarctic meiofauna in terms of diversity, number of specimens, distribution, and colonised substrates. Antarctic terrestrial biota are often characterised by high endemism (Chown and Convey, 2007) and it has 


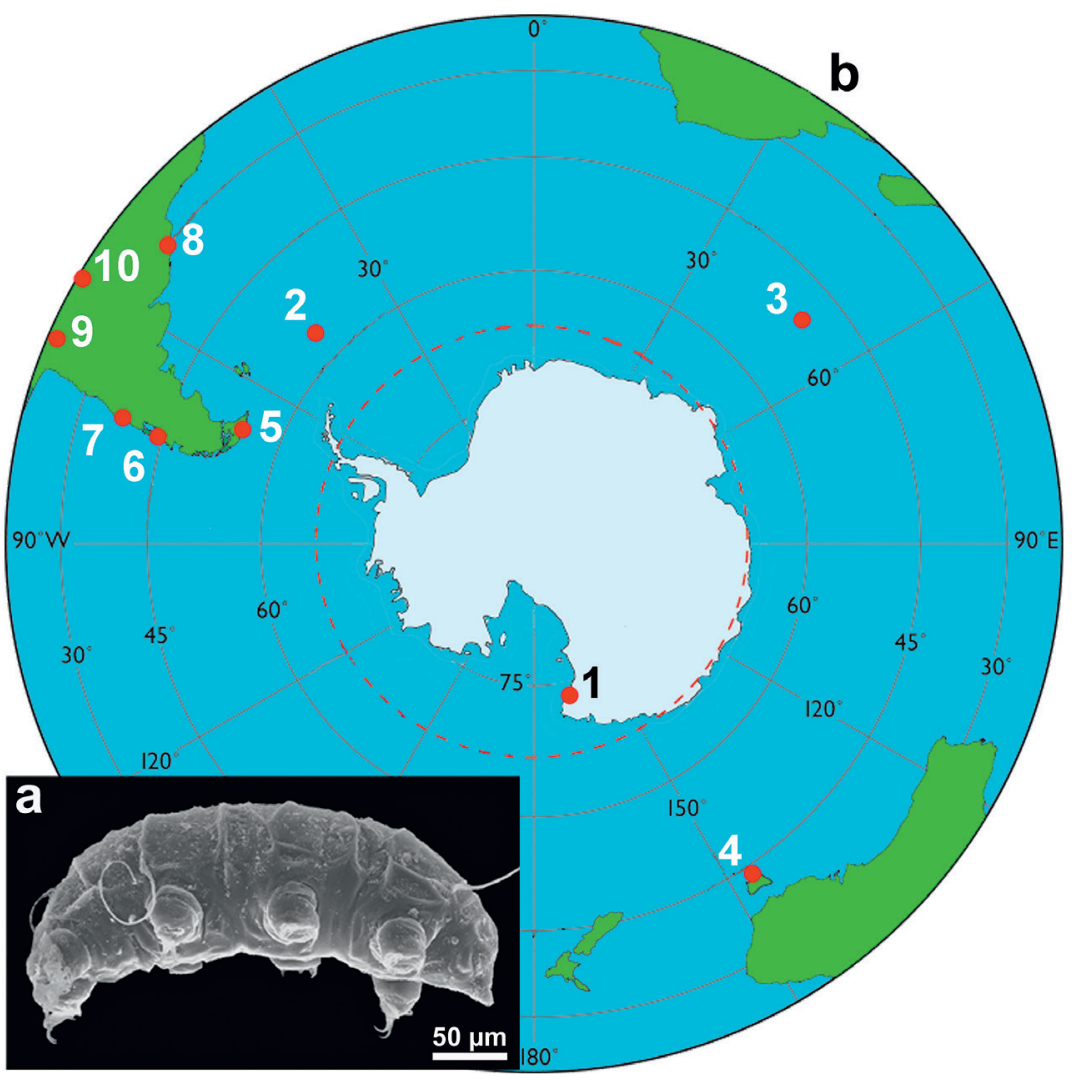

Fig 1. a Scanning electron micrograph of the heterotardigrade Mopsechiniscus franciscae. b Geographical distribution of the living species of Mopsechiniscus known to date (spots). 1 = Mopsechiniscus franciscae, Victoria Land, Antarctica; 2 = Mopsechiniscus imberbis, South Georgia, Sub-Antarctic Islands; 3 = Mopsechiniscus frenoti, Crozet Islands, Sub-Antarctic Islands; 4 = Mopsechiniscus tasmanicus, Tasmania, Australia; 5 = Mopsechiniscus sp., Chile; $6=$ Mopsechiniscus granulosus, Argentina; $7=$ Mopsechiniscus granulosus, Chile; $8=$ Mopsechiniscus sp., Brazil; $9=$ Mopsechiniscus schusteri, Venezuela; $10=$ Mopsechiniscus schusteri, Costa Rica. been hypothesised that long-term glacial habitat fragmentation and the consequent in situ isolation of biota was a likely cause (Stevens and Hogg, 2003, 2006).

Identifying biogeographic patterns and hypothesising species evolutionary origin are difficult tasks that require a combination of scientific disciplines and appropriate models. Understanding the origin and evolution of specific Antarctic biota requires finding particular taxa with clear biogeographic distributions. A fundamental element for investigating evolutionary biogeographic patterns is the definition of a temporal framework. Recent advances in molecular studies have provided novel chronological approaches in the form of molecular dating (a.k.a. molecular palaeobiology, or molecular clocks), which uses molecular and palaeontological analyses to provide a temporal framework. This framework can be used to explain evolutionary and geological events (Rota-Stabelli et al., 2013), and to test alternative biogeographic hypotheses.

Mopsechiniscus franciscae Guidetti et al., 2014 was recently discovered in Victoria Land, Antarctica (Guidetti et al., 2014; Fig. 1), and represents one of the only three heterotardigrade species found in continental
Antarctica. This new discovery, led us to evaluate the utility of this genus as a model taxon to test evolutionary patterns and biogeographical history within the timeframe of key Antarctic geological events. Mopsechiniscus is one of the few Echiniscidae for which there are molecular studies for more than one species (Jørgensen et al., 2011; Guidetti et al., 2014). Mopsechiniscus franciscae possesses the capability of cryptobiosis, which enables most limnic and terrestrial tardigrades to tolerate harsh climate conditions, such as those present in Antarctica (for reviews see Guidetti et al., 2011; Møbjerg et al., 2011; Wełnicz et al., 2011). This capability, coupled with their small body size $(<1$ $\mathrm{mm})$, may have provided tardigrades with a high advantage for dispersal and colonisation of Antarctica. However, until now, long distance dispersal has been demonstrated for a few terrestrial species only (Jørgensen et al., 2007; Cesari et al., 2009, 2016; Bertolani et al., 2011; Guidetti et al., 2016), and based on the limited distribution of most taxa, the tardigrade capability for long distance dispersal has been questioned (McInnes and Pugh, 1998; Pilato and Binda, 2001). Such as co-occurring micro-arthropods, Antarctic tar- 


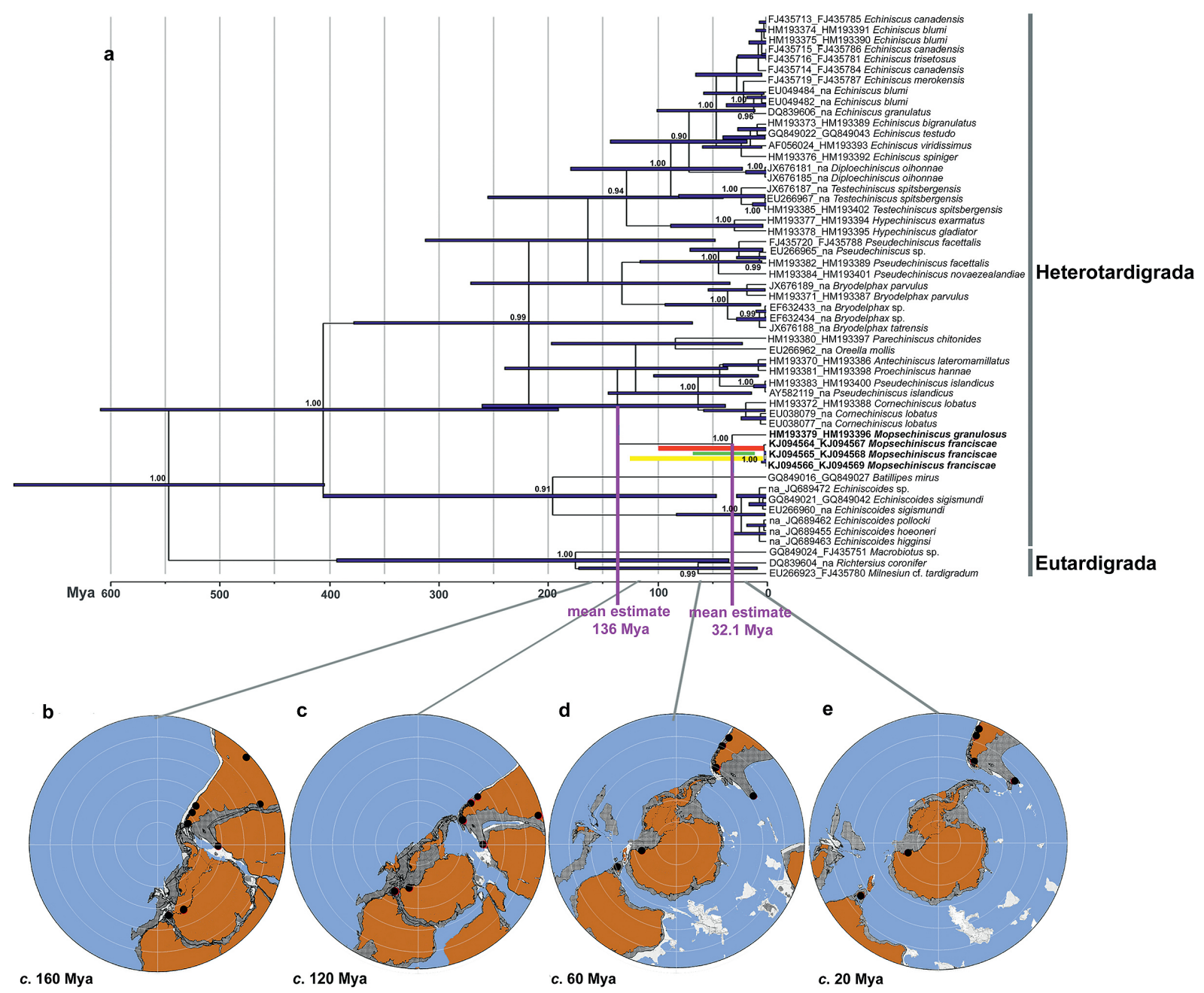

Fig 2. a Molecular clock analyses of the Heterotardigrada. Antarctic and South American Mopsechiniscus species (in bold) diverged approximately 32.1 My ago in a period highly compatible with the origin of the Drake Passage. Nodes are positioned at the mean divergence date, while bars indicate the $95 \%$ credibility intervals. The three coloured bars in the split between $M$. franciscae and $M$. granulosus indicate the $95 \%$ credibility interval from three independent analysis using different sets of evolutionary and palaeobiological priors. Red/ grey-dark bars correspond to a clock analysis using the rate deduced from Rota-Stabelli et al. (2013). Green/grey-bar corresponds to a clock analyses using the rate deduced from Rota-Stabelli et al. (2013) and a Log-normal distribution clock analysis (for full tree of this analysis see Fig. 3a). Yellow/grey-light bar corresponds to the analysis using secondary node constrains from Regier et al. (2004) (for full tree of this analysis see Fig. 3b). Values close to branches indicate posterior probability values ( $>0.9)$ of BI analysis. b-e Distribution of the extant Mopsechiniscus species (spots) mapped on the distribution of lands ca. 160 Mya (b), ca. 120 Mya (c), ca. 60 Mya (d), ca. 20 Mya (e). Figures of ancient land distributions (b-e) modified from Lawver et al. (1992). na = not available.

digrade distribution could represent a fauna comprising disjunct relicts (Marshall and Pugh, 1996; Pugh and Convey, 2000) or be the products of post-glacial speciation (Stevens and Hogg, 2003).

In order to shed new light on the origin and geochronology of the Antarctic continental fauna, we explored possible evolutionary scenarios for the origin of a component of the Antarctic meiofauna (i.e. the tardi- grade $M$. franciscae) using molecular dating analyses and historical biogeography.

\section{Material and methods}

Literature data were used to map the known distribution of Mopsechiniscus species on current and past 
Table 1. Tree and clock prior selection using Calibration set 1 . For each of the combinations of priors (Model 1 to 7 ), the mean estimates in mill model using Calibration set 1.

\begin{tabular}{|c|c|c|c|c|c|}
\hline & \multicolumn{2}{|l|}{ Model specification } & \multicolumn{3}{|c|}{ Posterior Age estimates (with 95\% Highest Posterior Density) } \\
\hline & Clock & Tree prior & $\begin{array}{l}\text { Tardigrada (root): Hetero- } \\
\text { Eutardigrada split }\end{array}$ & $\begin{array}{l}\text { First Heterotardigrada } \\
\text { split }\end{array}$ & $\begin{array}{l}\text { Origin of the line leading } \\
\text { to Mopsechiniscus }\end{array}$ \\
\hline Model 1 & strict & Coalescent & $557(692,417)$ & $500(644,361)$ & $151(205,105)$ \\
\hline Model 2 & relaxed random & Coalescent & $558(700,422)$ & $502(649,361)$ & $135(187,80)$ \\
\hline Model 3 & relaxed log-normal & Coalescent & $557(696,418)$ & $431(617,236)$ & $102(190,41)$ \\
\hline Model 4 & relaxed exponential & Coalescent & $558(692,411)$ & $339(569,110)$ & $59(149,12)$ \\
\hline Model 5 & relaxed exponential & Incomplete Birth-Death & $549(687,408)$ & $416(605,212)$ & $139(265,42)$ \\
\hline Model 6 & relaxed exponential & Birth-Death & $547(689,405)$ & $405(609,191)$ & $136(260,38)$ \\
\hline Model 7 & relaxed exponential & Yule process & $549(689,404)$ & $464(628,296)$ & $158(288,70)$ \\
\hline
\end{tabular}

$\mathrm{BF}=$ Bayes factors

landmass maps to define their distribution patterns (Richters, 1907, 1920; Du Bois-Reymond Marcus, 1944; Ramazzotti, 1962; Mihelčič, 1967, 1971/72; Grigarick et al., 1983; Binda and Kristensen, 1986; Kristensen, 1987; Rossi and Claps, 1989; Ottesen and Meier, 1990; Rossi et al., 2009; Dastych and Moscal, 1992; Dastych, 1999a, b c, 2000, 2001; Kaczmarek et al., 2014; Guidetti et al., 2014; Roszkowska et al., 2016).

For molecular phylogenetics and dating analyses, we assembled a concatenated dataset of $18 \mathrm{~S}$ (SSU, $686 \mathrm{bp}$ corresponding to positions 1213-1899 of the Echiniscus canadensis $18 \mathrm{~S}$ complete sequence, Genbank Acc. No. FJ435714) and 28S (LSU, 968 bp corresponding to positions 1194-2192 of the E. canadensis $28 \mathrm{~S}$ complete sequence, Genbank Acc. No. FJ435784) rRNA, as they are the only gene fragments available for Mopsechiniscus species. Sequences from three M. franciscae specimens, one Mopsechiniscus granulosus Mihelčič, 1967 specimen, 46 other Heterotardigrada (belonging to 32 recognised species), and three Eutardigrada used as outgroups, were retrieved and downloaded from GenBank (accession numbers are provided in Fig. 2). Sequences of $18 \mathrm{~S}$ and $28 \mathrm{~S}$ were aligned individually with MUSCLE 3.8.31 (Edgar, 2004) using a default run followed by two refinement runs (using option -refine), and concatenated using an in house PERL script, then they were checked by visual inspection. This resulted in a dataset (main dataset) of 53 sequences belonging to 36 taxa and 1655 positions, and 51\% of missing data. To account for alignment quality and the effect of missing data, we generated a second dataset with the same taxon sampling but customised to exclude various positional gaps, which are present in all Heterotardigrada (insertions in the distantly related Eutardigrada) or poorly represented along the alignment. This dataset (reduced-dataset) comprises 53 sequences belonging to 36 taxa and 824 positions, and $20 \%$ of missing data. Analyses were conducted in BEAST v1.8 (Drummond and Rambaut, 2007) using a homogenous GTR model of nucleotide replacement coupled with a gamma distribution with four discrete categories. Best fitting model evaluations were performed taking into account the Akaike information criterion and Bayes information criterion (jModelTest 0.0.1; Posada, 2008). All BEAST analyses were run twice for 10 million generations each, sampling every 1000 generations, and using a starting random tree. Convergence of the most relevant parameters was checked with Tracer v1.6 and a consensus divergence tree was calculated with TreeAnnotator v1.8.2 using a burning-in of 1000 sampled trees.

Since time estimates are sensitive to tree and clock priors settings, we performed a model selection using Bayes factors based on the log marginal likelihoods, which were estimated using the smoothed harmonic mean method (Suchard et al., 2001) on 100 bootstrap replicates. Various combinations of priors were tested by running the main dataset with calibration set 1 (see below) in BEAST and varying one tree/clock prior at the time (Table 1). The strict, the relaxed random, the relaxed lognormal, and the relaxed exponential clocks were all tested as clock priors; the coalescent, the Birth Death, the incomplete Birth Death, and the Yule process were tested as tree priors. According to the test, positive values of $2 \operatorname{lnBF}$ difference from different runs indicated the better fit of a model combination over a previously ranking model combination. Significance of the Bayes factor was assessed in accordance with Kass and Raftery's (1995) table.

With no fossil or sub-fossil records to constrain the Heterotardigrada, the clock was calibrated using two 
ions of years for four nodes of interest are provided; the heights of the 95\% Highest Posterior Density are in parenthesis. In bold the most fitting

\begin{tabular}{|c|c|c|c|c|c|}
\hline \multirow[b]{2}{*}{ M. franciscae-M. granulosus split } & \multicolumn{5}{|c|}{ Model selection } \\
\hline & $\ln \mathrm{BF}$ & $\begin{array}{l}\text { ln BF to } \\
\text { highest }\end{array}$ & $\begin{array}{l}2 \ln \mathrm{BF} \text { to } \\
\text { previous }\end{array}$ & rank & significance \\
\hline $34.9(59,15)$ & -6112.7 & 0.1 & 0.3 & 6 & not significant \\
\hline $35.1(60,16)$ & -6112.8 & lowest & lowest & 7 & - \\
\hline $29.1(66,7)$ & -6097.1 & 15.8 & 31.2 & 5 & very strong \\
\hline $19(60,2)$ & -6092.3 & 20.5 & 9.5 & 4 & strong \\
\hline $32.7(91,4)$ & -6091.5 & 21.3 & 1.6 & 3 & not significant \\
\hline $32.1(99,3)$ & -6089.4 & 23.4 & 2.4 & BEST & positive \\
\hline $61.2(147,14)$ & -6090.6 & 22.2 & 1.8 & 2 & not significant \\
\hline
\end{tabular}

distinct calibration-sets based on replacement rates and posterior estimates for the split of the Eutardigrada derived from previous studies (Regier et al., 2004; RotaStabelli et al., 2013). For calibration-set-1, the clock was calibrated using the replacement rate of 0.001564 mutations per site per million years (mut/site/My), with standard deviation (SD) of $0.001012 \mathrm{mut} / \mathrm{site} / \mathrm{My}$, based on the analysis of $18 \mathrm{~S}$ and 28S rDNA genes from a wide range of ecdysozoans (including the tardigrade clade), together with a permissive root prior of 579 Mya, SD 70 My (allowing sampling 95\% of quantiles from 463 to 716 Mya) (Rota-Stabelli et al., 2013). An alternative calibration strategy (calibration-set 2) was employed using, as a root prior, a more restrictive distribution (compared to the first) centred on 659 Mya (SD $20 \mathrm{My}$; to allow 95\% of sampling between 626 and $691 \mathrm{Mya}$ ) and by constraining two nodes within the eutardigrade outgroup (Macrobiotidae 144 Mya, SD 15 My; Eutardigrada 453 Mya, SD 12 My); this substantially different approach is based on the results of Regier et al. (2004), who build a posterior time estimate for some tardigrade clades. To check for the effect of the dataset on divergence times, we repeated the molecular clock analysis on the reduced-dataset using both calibration-set 1 and calibration-set 2 .

\section{Results and discussion}

Molecular clock analyses

\section{Test of model fit}

Results of the model selection based on Bayes factors (BF, Table 1) indicated that the best fitting model em- ployed a combination of a relaxed exponential clock and a Birth-Death model of tree diversification. We used this combination of priors for subsequent analyses (Tables 2, 3). The difference in BF to other model combinations was quite low (BF 2.4 over the second ranking model), but enough to set this model as favoured. In general, model combinations involving a relaxed exponential were "strongly" favoured over the relaxed lognormal, the latter being in turn "very strongly" favoured over the strict and the random clock models. As for the tree priors, the difference between the Coalescent and the three Birth-Death type processes we tested was very low.

Because the difference of the marginal likelihood using different priors was extremely low, we advocated great care in interpreting the result of our model selection: Table 1 is however a good indication for future tardigrade clock studies using RNA sequences, rather than as decision maker to discriminate among competing time estimates.

\section{Molecular dating}

Our results for the tardigrade phylogenetic relationships, based on the best fitting priors deduced from Table 1 and using calibration-set 1 (Fig. 2), were congruent with previous studies (Jørgensen et al., 2011; Guil and Giribet, 2012; Guil et al., 2013; Vicente et al., 2013; Guidetti et al., 2014). By employing different calibration sets (Table 2), and testing the effect of site selection (Table 3), we have attempted to account for the uncertainty imbedded in molecular clock studies.

The analyses conducted using two different calibration sets (Table 2) provided different estimates. Nonetheless, from the results, it was possible to infer the 
Table 2. Molecular dating using two different sets of calibration priors. Analyses were conducted using the complete dataset and the most fitting vide the mean estimates in millions of years for four nodes of interest; the heights of the 95\% Highest Posterior Density are in parenthesis.

\begin{tabular}{|c|c|c|c|c|c|}
\hline & \multicolumn{3}{|c|}{ Calibration priors } & \multicolumn{2}{|c|}{ Posterior Age estimates (with 95\% Highest Posterior Density) } \\
\hline & Root prior & Costrains & Rate prior & $\begin{array}{l}\text { Tardigrada (root): Hetero- } \\
\text { Eutardigrada split }\end{array}$ & $\begin{array}{l}\text { First Heterotardigrada } \\
\text { split }\end{array}$ \\
\hline Calibration-set 1 & $579(716,463)$ & none & 0.00156 & $547(689,405)$ & $405(609,191)$ \\
\hline Calibration-set 2 & $659(691,626)$ & $\begin{array}{l}\text { Eutard. (453 SD 12) } \\
\text { Macro. (144 SD 15) }\end{array}$ & no prior & $659(697,619)$ & $521(677,314)$ \\
\hline Average & & & & $603(693,512)$ & $563(643,253)$ \\
\hline $\begin{array}{l}\text { Most estimates } \\
\text { falling in: }\end{array}$ & & & & Cryogenian/ Ediacaran & Cambrian (Paleozoic) \\
\hline
\end{tabular}

Eutard. $=$ Eutardigrada origin. Macro. $=$ Macrobiotidae origin $. \mathrm{BF}=$ Bayes factors

Table 3. Molecular clock analyses using reduced-datasets. Analyses were conducted using the most fitting relaxed clock and tree prior as defined nodes of interest are provided; the heights of the $95 \%$ Highest Posterior Density are in parenthesis.

\begin{tabular}{|c|c|c|c|c|c|}
\hline & \multicolumn{3}{|c|}{ Calibration priors } & \multicolumn{2}{|c|}{ Posterior Age estimates (with 95\% Highest Posterior Density) } \\
\hline & Root prior & Costrains & Rate prior & $\begin{array}{l}\text { Tardigrada (root): Hetero- } \\
\text { Eutardigrada split }\end{array}$ & $\begin{array}{l}\text { First Heterotardigrada } \\
\text { split }\end{array}$ \\
\hline Calibration-set 1 & $579(716,463)$ & none & 0.00156 & $548(689,405)$ & $498(592,170)$ \\
\hline Calibration-set 2 & $659(691,626)$ & $\begin{array}{l}\text { Eutard. (453, SD 12) } \\
\text { Macro. (144, SD 15) }\end{array}$ & no prior & $662(699,622)$ & $482(657,300)$ \\
\hline Average & & & & $605(694,514)$ & $490(625,235)$ \\
\hline $\begin{array}{l}\text { Most estimates } \\
\text { falling in: }\end{array}$ & & & & Cryogenian/ Ediacaran & Cambrian (Paleozoic) \\
\hline
\end{tabular}

Eutard. $=$ Eutardigrada origin. Macro. $=$ Macrobiotidae origin $. \mathrm{BF}=$ Bayes factors

root of the tree, i.e. when the Heterotardigrada and Eutardigrada lines split apart, showing to be at 659 and 547 Mya, which was before the Cambrian Period (Table 2). The two methods also produced similar mean estimates, 146 and 136 Mya (early Cretaceous), for the divergence of the lineage that led to Mopsechiniscus, though the 95\% Highest Posterior Density (95\% HPD) for this node was very wide (ranging from 294 to 38 Mya). Both methods placed the split between the phylogenetic lines of the Mopsechiniscus species (M. franciscae: Antarctica; Guidetti et al., 2014 and M. granulosus: Chile; Jørgensen et al., 2011) between 47.8 and 32.1 Mya (Paleogene, during late Eocene early Oligocene), with a 95\% HPD of 131-3 Mya (Table 2; Fig. 2). Analyses conducted on the reduced-dataset produced similar estimates (Table 3; Fig. 3) with average data in line with: a possible pre-Cambrian origin of the Tardigrada; an early Cretaceous-Eocene origin for the lineage that led to Mopsechiniscus; a late Paleogene split between $M$. franciscae and M. granulosus.

Although the mean estimates were concordant for various nodes, particularly those describing the origin of $M$. franciscae, the range of visited posterior estimates was extremely large in all the analyses (see Tables 2 and 3 for a breakdown of the 95\% HPD): overall, this indicated a large uncertainty in the precise estimation of tardigrade radiation using RNA $18 \mathrm{~S}$ and $28 \mathrm{~S}$ makers. This may be caused by a variety of reasons. First, the paucity of calibration priors currently available for tardigrades forced us in relying mostly on prior replacement rates with relatively high standard deviations: this likely reflected in highly uncertain posterior estimates. Second, the relatively short length of the alignment and the high amount of missing data may have inserted a high stochastic effect. This possibility was reinforced by the range of the HPD being slightly smaller when using a reduced (less missing data) dataset (compare Tables 2 and 3). Finally, the fast evolving nature of tardigrade genes (Campbell et al., 2011) may have complicated the correct estimation of their divergence; this possibility is compatible with a study of Ecdysozoan evolution showing that tardigrade 
relaxed clock and tree prior as defined in Table 1 (relaxed exponential clock plus Birth Death process). For each of the calibration sets, we pro-

Model selection

\begin{tabular}{lll}
\hline $\ln \mathrm{BF}$ & $\begin{array}{l}2 \text { ln BF to } \\
\text { previous }\end{array}$ & rank \& significance \\
\hline-6089.42 & - & - \\
-6088.46 & 1.93 & BEST, not significant
\end{tabular}

$141(277,41)$

Jurassic (Mesozoic)

in Table 1 (relaxed exponential clock plus Birth Death process). For each of the calibration-sets, the mean estimates in millions of years for four

\begin{tabular}{|c|c|c|c|c|c|}
\hline \multirow[b]{2}{*}{$\begin{array}{l}\text { Origin of the line leading to } \\
\text { Mopsechiniscus }\end{array}$} & \multirow[b]{2}{*}{$\begin{array}{l}\text { M.franciscae-M. granulosus } \\
\text { split }\end{array}$} & \multicolumn{4}{|c|}{ Model comparison } \\
\hline & & $\ln \mathrm{BF}$ & $\begin{array}{l}\text { ln BF to } \\
\text { highest }\end{array}$ & $\begin{array}{l}2 \ln \mathrm{BF} \text { to } \\
\text { previous }\end{array}$ & rank \& significance \\
\hline $124(241,36)$ & $29.7(91,3)$ & -4281.27 & lowest & lowest & 3 \\
\hline $178(294,66)$ & $43.7(124,9)$ & -4277.19 & 4.07 & 8.15 & 2 , strong \\
\hline $151(268,51)$ & $36.7(108,6)$ & & & & \\
\hline Jurassic (Mesozoic) & Paleogene (Cenozoic) & & & & \\
\hline
\end{tabular}

divergence was the most unstable within the sample, with estimates strongly varying with parameter variations (Rota-Stabelli et al., 2013). Overall, our molecular dating of the Heterotardigrada indicated that their divergence estimate is a complex issue which should be tackled in the future by employing more markers and possibly outgroups to the tardigrades in order to allow external calibrations.

\section{Origin and distribution of Mopsechiniscus}

\section{Biogeographical distribution and ecology of Mopse-} chiniscus species

Reports of Mopsechiniscus species are largely confined to the Southern Hemisphere, with the most northern reference to be found for Costa Rica, and the majority of references from South America (Venezuela, Brazil, Argentina, and Chile), southern Australia, sub-Antarctic, and continental Antarctica (Fig. 1). In particular, four of the six described species are considered endemic and have been found only in the type localities: Mopsechiniscus imberbis (Richters, 1907) from South Georgia, sub-Antarctic (Richters, 1907, 1920; Ottesen and Meier, 1990); Mopsechiniscus franciscae from Victoria Land, Antarctica (Guidetti et al., 2014); Mopsechiniscus tasmanicus Dastych and Moscal, 1992 from Tasmania, Australia (Dastych and Moscal, 1992); and Mopsechiniscus frenoti Dastych, 1999, from the Île de la Possession, Crozet Islands, sub-Antarctic (Dastych, 1999c). Mopsechiniscus schusteri Dastych, 1999 has been reported from Venezuela (Grigarick et al., 1983; Dastych, 1999a) and Costa Rica (Kaczmarek et al., 2014); and Mopsechiniscus granulosus Mihelčič, 1967 has been reported from several Argentinean localities (Mihelčič, 1967, 1971/72; Binda and Kristensen, 1986; Kristensen, 1987; Rossi and Claps, 1989; Dastych, 2000; Rossi et al., 2009; Roszkowska et al., 2016) and Chile (Ramazzotti, 1962; Dastych and Moscal, 1992; Dastych, 2000). According to Dastych (1999a, 2001), there are two 

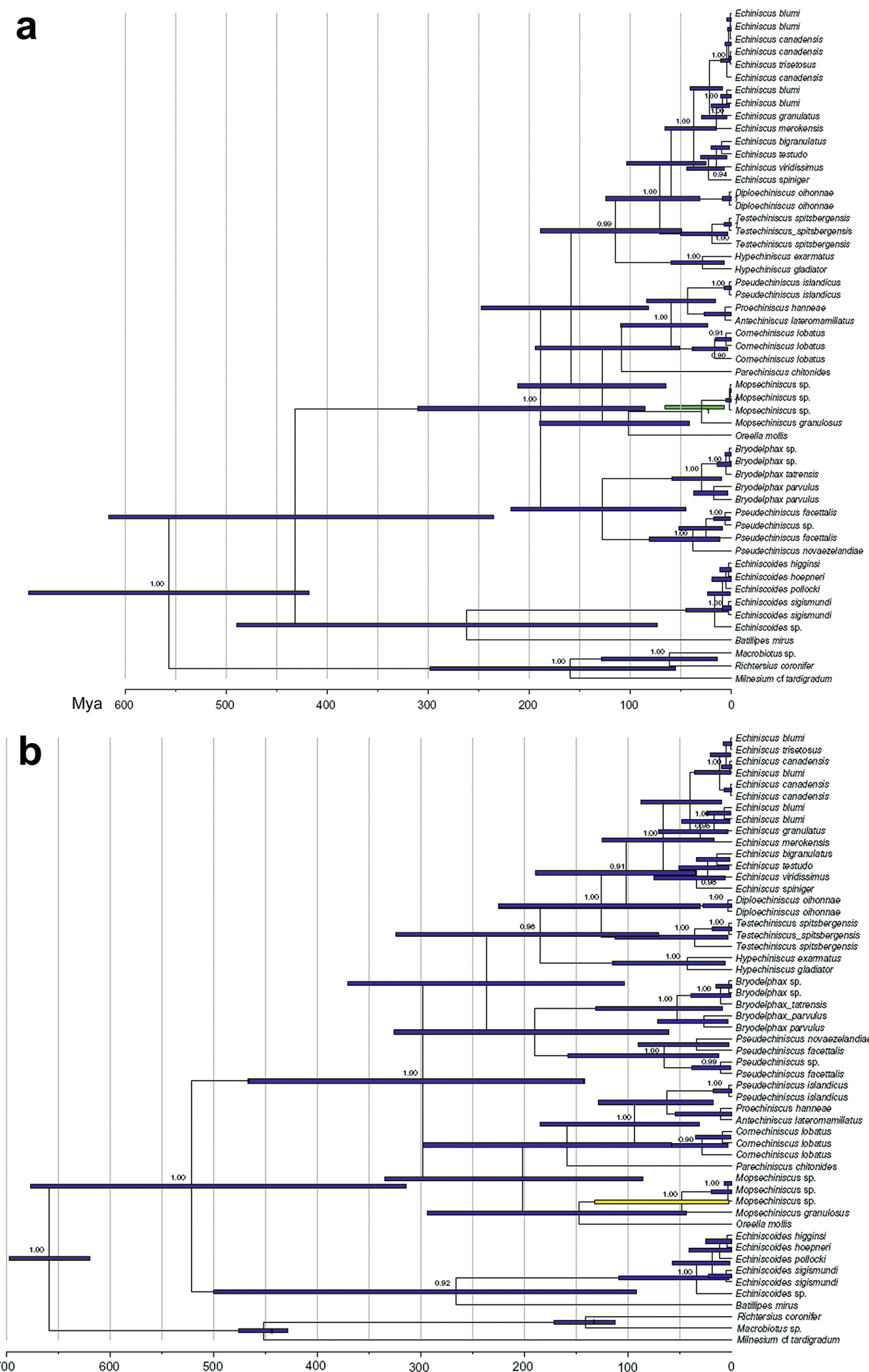
more undescribed new species from Brazil (Du BoisReymond Marcus, 1944), and Chile. The distribution of Mopsechiniscus species point to a Gondwanan distribution for the genus, as has already been hypothesized (Dastych and Moscal, 1992; Dastych, 2001).

However, ecological data on Mopsechiniscus species are very limited (see Dastych, 2001). The species of this genus have been found in moss and lichens, rarely liverworts, at different altitudes. An association with environments rich in Nothofagus forests has also been noted (Ramazzotti, 1962; Kristensen, 1987; Dastych \& Moscal, 1992). In sub-Antarctic islands, Mospechiniscus was found at 70-700 $\mathrm{m}$ a.s.l., in Tierra del Fuego at $c a .1000 \mathrm{~m}$ (above the tree line), in subtropical and/or cloud forest from $50 \mathrm{~m}$ up to $2000 \mathrm{~m}$, suggesting a mountain and/or subpolar character of the genus (Dastych, 2001). The Antarctic species (M.franciscae) used in this study was found in a large patch of moss growing on gravel soil in a very small valley at Crater Cirque (Guidetti et al., 2014), while the South American species (M. granulosus) was collected at Angol in Chile, though the original substrate was not reported (Jørgensen et al., 2011).

\section{Mopsechiniscus in Antarctica}

Three scenarios could account for the presence of Mopsechiniscus in Antarctica, in addition to South America: 1) an early ancestor and speciation occurring early during the initial break-up of Gondwana ( $c a .150$ Mya); 2) speciation occurring after the break between Antarctica from South America (ca.30 Mya); 3) recent colonisation via zoogenic introduction (e.g. penguins or sea birds), wind dispersal, and/or anthropogenic activities.

At the species level, modern molecular methods have revealed a remarkable level of endemism of the Antarctic biota, questioning the widespread assumption that small organisms are likely to be ubiquitous and the taxa to which they belong species poor (Chown and Convey, 2007). Recent molecular analyses showed that most Antarctic tardigrades appear to be locally endemic, with a greater diversity than had previously been considered. There were also potentially undescribed species, and a lack of connectivity between most Operational Taxonomic Units from continental
Antarctica and those from other Antarctic geographical zones (Velasco-Castrillón et al., 2015). Endemism is very high for maritime and continental Antarctic tardigrade species (more than 80\%), with less than 3\% of the species in common with taxa from South America, and even fewer when comparing only continental Antarctic species (McInnes, 1994; Velasco-Castillo et al., 2014; Kaczmarek et al., 2015). Some species, e.g. Acutuncus antarcticus (Richters, 1904) and Milnesium antarcticum Tumanov, 2006, are widespread across continental Antarctica, while others have a very limited distribution within this continent (Sohlenius and Boström, 2005; Velasco-Castrillón et al., 2015; Cesari et al., 2016).

This situation is not limited to tardigrades, but occurs also in other representatives of the terrestrial meiofauna with cryptobiotic adaptations, like nematodes and rotifers. These animals show a very similar distribution pattern, e.g. all Victoria Land nematodes are endemic to Antarctica, and many are common and widely distributed at landscape scale (Adams et al., 2014). For rotifers, the level of endemism in Antarctica is $95 \%$ of the species, higher than any other continent, with many bdelloid species occurring only in maritime or continental Antarctica (Iakovenko et al., 2007). Molecular studies showed a widespread range for some rotifers in continental Antarctica, but only one bdelloid lineage from continental Antarctica was also present in maritime Antarctica, and no close similarities were found with worldwide locations, or between Antarctic Peninsula and Tierra del Fuego (Argentina) (Velasco-Castrillón et al., 2014).

Based on these findings, anhydrobiotic metazoans living in Antarctica (i.e. tardigrades, nematodes, and rotifers) show a restricted distribution, with high percentage of endemic Antarctic taxa, in spite of their potential for high dispersal. Therefore, it is extremely unlikely that the high number (33) of endemic tardigrade species in Antarctica (including two endemic genera) are the result of speciation after recent colonisation. The literature portrays a very limited and/ or endemic distribution for Mopsechiniscus species, and for continental Antarctica a very reduced presence of echiniscids. This information implies a relatively low dispersal capability for these taxa and, therefore, few possibilities for recent colonisation events. Although,

Fig 3. a Molecular clock analysis of the Heterotardigrada using the rate deduced from Rota-Stabelli et al. (2013) and a Log-normal distribution clock analysis. b Molecular clock analysis of the Heterotardigrada using secondary node constraints from Regier et al. (2004). Values close to branches indicate posterior probability values $(>0.9)$ of BI analysis while bars indicate the $95 \%$ credibility intervals. 
it cannot be excluded, the third scenario, a recent colonisation of Antarctica, is very unlikely for Mopsechiniscus species. If the presence of $M$. franciscae in Antarctica was the result of a recent colonization, this event would have to be considered extremely rare as no other tardigrade species reported from continental Antarctica have been recorded elsewhere in the world, the exception being a single record (to be confirmed) of $A$. antarcticus (the most common and widespread Antarctic tardigrade species) in Tierra del Fuego (Claps et al., 2008).

According to the molecular clock, the origin of the genus Mopsechiniscus can be placed somewhere between the origin of its phylogenetic line (i.e. when it separated from its sister taxon; 146-136 Mya) and the split between M. franciscae and M. granulosus (47.832.1 Mya) (Table 2). This is after Gondwana separated from Laurasia (ca. 200-180 Mya), but before the complete breakup of Gondwana ( $c a$. 50-30 Mya). This time frame for the origin of the genus and the current distribution of Mopsechiniscus species (Fig. 1; see above) indicate a Gondwanan presence of the genus during the Mesozoic period.

If a more anterior time for the origin of Mopsechiniscus is chosen, e.g. close to the lower limit of the $95 \%$ HPD (294 Mya), then the genus would have been extant during the period of existence of the super-continent Pangea (from about 300 Mya until its breakup about $180 \mathrm{Mya}$ ). In this scenario, the distribution of the genus would have to have been confined to the Gondwana region of the Pangea throughout the $120 \mathrm{My}$ of super-continent's duration. A later time for the origin of Mopsechiniscus, e.g. close to the upper limit of the 95\% HPD (3 Mya), would require a very late colonisation of three continents and a subsequent rapid speciation within the genus. Again, not the most parsimonious option. According to Dastych (2001), and as discussed above, Mopsechiniscus represents a Gondwanan faunal element with a distribution pattern that is a result of historical factors and subsequent speciation, rather than purely dispersal events.

Our two main analyses (Tables 2,3) and those used for model comparison (Table 1) returned congruent mean estimates, falling within a time range of 48-32 Mya, for the split between the Antarctic and the South American Mopsechiniscus lineages. This is compatible with the estimated separation of Antarctica and South America (e.g. Livermore et al., 2005), in which the opening of the Drake Passage prevented exchanges of organisms by land and reduced the dispersal ranges of species. The strongly debated estimate for the origin of this passage ranges approximately from 50 to 20 Mya, but in most cases not earlier than the cooling period that followed the Eocene/Oligocene boundary (33.7 Mya; Livermore et al., 2005). Recent geological studies also indicate that the Drake Passage opening is older than 28.5 Mya (Dalziel et al., 2013). Estimates for the general break-up of Australia, Antarctica and South America derived from a molecular clock analysis on Nothofagus, the southern beech with a Gondwanan distribution (Zhang, 2011), provided a range of 50-30 Mya (Cook and Crisp, 2005). All these independent studies on the dating of the geological events that separated Antarctica from South America indicate a time similar to our results for the separation of the respective Mopsechiniscus lineages.

Therefore, our molecular clock analyses support vicariance for the $M$. franciscae speciation caused by the separation of Antarctica and South America. The scenario of recent dispersal and re-colonisation is very unlikely, as stated previously, but due to the high 95\% HPD range alternative scenarios cannot be excluded.

Interestingly, the proposed permanent glaciation of Antarctica at 34 Mya (Scher and Martin, 2006) could have accelerated the geographic isolation of Mopsechiniscus populations; the reduction of the available habitats increased the distance between, and reduced the number of, populations, with clear consequences for the subsequent speciation process. Therefore, the allopatric speciation of Antarctic tardigrades could be the consequence of two geographical separation/ isolation promoting events: the separation between Antarctica and South America and the glaciation of Antarctica.

If our hypothesis is correct, the vicariance events have separated the Mopsechiniscus lineages and isolated M. franciscae (and possibly other tardigrade endemic species) in Antarctica, implying that this species represents a relict faunal fragment that survived the Last Glacial Maximum (LGM; ca. 20,000 years ago). Even the lower 95\% HPD limit (3 Mya) for the origin of the Antarctic Mopsechiniscus lineage would indicate a long presence in Antarctica, and the consequent survival through the extreme conditions present during the LGM.

Other possible scenarios for the presence of $M$. franciscae in Antarctica cannot be excluded, although we consider them unlikely for the reasons explained above. As M. franciscae is the only Mopsechiniscus species identified in Antarctica, other speciation processes (e.g. sympatric or parapatric speciation) are 
very improbable. In principle, a recent colonization of Antarctica by $M$. franciscae either from unexplored regions or by another Mopsechiniscus species followed by speciation is possible. Both scenarios would imply a high dispersal capability and a wide distribution outside Antarctica; two characteristics for which there is currently no evidence, and therefore should be considered improbable. The presence of $M$. franciscae in Antarctica could represent the result of regional extinctions outside Antarctica, or of other Mopsechiniscus species (e.g. M. granulosus) within Antarctica. This scenario would suggest the coexistence of more than one Mopsechiniscus species in an area, a situation that has never been reported.

\section{Mopsechiniscus in the sub-Antarctic islands}

The presence of Mopsechiniscus on two sub-Antarctic islands is intriguing. South Georgia, where M. imberbis is found, is recognised as a micro-continent that has geological links with the Patagonian Andean Mountains, situated to the east of the Beagle Channel and attached to the southern margin of the Burdwood Bank (Dalziel et al., 1975). There is some debate over the positioning and subsequent movement of this micro-continental plate during the late Cretaceous-early Paleogene period (Dalziel et al., 1975; Barker, 2001; Thomson, 2004). Lawver and Gahagan (2003) provide a computerised continental break-up history of whole Antarctica, placing South Georgia to the south of Burdwood Bank and in close proximity to Tierra del Fuego. With the addition of our results for the estimated molecular clock division between two phylogenetic lineages (the Antarctic $M$. franciscae and the South American M. granulosus), the latter scenario is congruent with the hypothesis that Mopsechiniscus was present on South Georgia before it broke away from Tierra del Fuego.

Mopsechiniscus frenoti of the Crozet Islands is morphologically very similar to $M$. franciscae from Antarctica (Guidetti et al., 2014) and, based on the available data, we can infer that the two species represent sister taxa within the genus. The volcanic rocks of the sub-Antarctic Crozet archipelago have a relatively recent origin (ca.8.8 Mya; Giret et al., 2003). Howev$\mathrm{er}$, the origins of the islands on the Crozet Plateau are debated (see Craig, 2003). Suggested interpretations of palaeogeographic data put these islands near India, close to Madagascar or off Antarctica over a period between late Cretaceous ( $\mathrm{ca}$. $70 \mathrm{Mya}$ ) to the Palaeocene (60-63 Mya) (Craig, 2003). The Crozet Islands host a number of indigenous species including plants, carabid beetles, and black flies (Chown et al., 1998; Vernon et al., 1999; Craig et al., 2003). How these indigenous flora and fauna, and indeed Mopsechiniscus, reached the islands is unknown. Winds and birds are potential vectors, especially as the Crozet Islands would have been formed $1,000 \mathrm{~km}$ closer to Africa during the Palaeocene (Schlich et al., 1974), but there is no evidence that passive long distance dispersal is common for Mopsechiniscus.

It is entirely possible that Mopsechiniscus species indigenous of South Georgia and the Crozet Islands could also be present in localities we have not yet discovered. Alternatively, they may have become isolated on the islands by traversing land/island bridges that have by now vanished.

\section{Conclusions}

A species' geographical distribution is the result of a variety of spatio-temporal events, including among others vicariant speciation, diffusion, jump dispersal, extinction, and colonisation. Although we were not able to give a definitive evidence, Mopsechiniscus was shown to be an ancient tardigrade genus with a Gondwanan distribution that has been further articulated at species level by geological events. Our molecular dating, with all its uncertainty, provided an estimate of when two Mopsechiniscus phylogenetic lineages separated. According to these results, the allopatric speciation of M. franciscae and M. granulosus could coincide with two geographical separation/ isolation promoting events: the break-up of Gondwana and the glaciation of Antarctica; our divergence estimates are indeed congruent with other independent studies in dating Gondwanan geological events. From a methodological point of view, our molecular clock results indicated that the molecular dating of tardigrades (using genes coding for ribosomal RNA) is extremely complicated and accompanied by a high degree of uncertainty revealed by: a very wide \% HPD, a variable estimate when varying priors, and a relative difficulty in discriminating between competing models. Future studies could increase the number of genes and the taxa considered in the analyses, which should reduce the HPD values.

Overall, our results indicate that Mopsechiniscus can be used for biogeographical and temporal studies, paving the way to further studies to better understand the origin of Antarctic microfauna. 


\section{Acknowledgements}

This study was supported by the project "Evolutive and phylogeographic history of Antarctic organisms and responses by ecosystems to climatic and environmental changings", (PEA 2013) supported by Programma Nazionale Ricerche in Antartide (PNRA) - Ministero dell'Istruzione dell'Università e della Ricerca (MIUR). We thank two anonymous reviewers.

\section{References}

Barker PF. 2001. Scotia Sea regional tectonic evolution: implications for mantle flow and palaeocirculation. Earth-Science Reviews 55: 1-39.

Barnes DKA, Hodgson DA, Convey P, Allen CS, Clarke A. 2006. Incursion and excursion of Antarctic biota: past, present and future. Global Ecolology and Biogeography 15: 121-142.

Bertolani R, Rebecchi L, Giovannini I, Cesari M. 2011. DNA barcoding and integrative taxonomy of Macrobiotus hufelandi CAS Schultze 1834, the first tardigrade species to be described, and some related species. Zootaxa 2997(19): e36.

Binda MG, Kristensen RM. 1986. Notes on the genus Oreella (Oreellidae) and the systematic position of Carphania fluviatilis Binda, 1978 (Carphanidae Fam. Nov., Heterotardigrada). Animalia 13: 9-20.

Campbell LI, Rota-Stabelli O, Edgecombe GD, Marchioro T, Longhorn SJ, Telford MJ, Philippe H, Rebecchi L, Peterson KJ, Pisani D. 2011. MicroRNAs and phylogenomics resolve the relationships of Tardigrada and suggest that velvet worms are the sister group of Arthropoda. Proceeding of the National Academy of Science 108: 15920-15924.

Cesari M, Bertolani R, Rebecchi L, Guidetti R. 2009. DNA barcoding in Tardigrada: the first case study on Macrobiotus macrocalix Bertolani \& Rebecchi 1993 (Eutardigrada, Macrobiotidae). Molecular Ecology Resources 9(3): 699-706.

Cesari M, McInnes SJ, Bertolani R, Rebecchi L, Guidetti R. 2016. Genetic diversity and biogeography of the south polar water bear Acutuncus antarcticus (Eutardigrada: Hypsibiidae)-evidence that it is a truly pan-Antarctic species. Invertebrate Systematics 30(6): 635-649.

Chown SL, Convey P. 2007. Spatial and temporal variability across life's hierarchies in the terrestrial Antarctic. Philosophical Transaction of the Royal Society of London B 362: 2307-2331.

Chown SL, Gremmen NJM, Gaston KJ. 1998. Ecological Biogeography of Southern Ocean Islands: Species-Area Relationships, Human Impacts, and Conservation. The American Naturalist 152: 562-575.

Claps MC, Rossi GC, Ardohain DM. 2008. Tardigrada. Pp. 63-77 in: Claps LE, Debandi G, Roig-Juñent S eds, Biodiversidad de Artrópodos Argentinos. Vol. 2. Sociedad Entomológica. Mendoza, Argentina.

Convey P. 2010. Terrestrial biodiversity in Antarctica - Recent advances and future challenges. Polar Science 4: 135-147.

Convey P, Gibson JAE, Hillenbrand CD, Hodgson DA, Pugh PJA, Smellie JL, Stevens MI. 2008. Antarctic terrestrial life-challenging the history of the frozen continent? Biological Reviews 83: 103-117.
Convey P, Stevens MI, Hodgson DA, Smellie JL, Hillenbrand C-D, Barnes DKA. 2007. Antarctic biodiversity. Science 317: $1877-1878$.

Cook LG, Crisp MD. 2005. Not so ancient: the extant crown group of Nothofagus represents a post-Gondwanan radiation. Proceedings of the Royal Society B 272: 2535-2544.

Craig DA. 2003. Deconstructing Gondwana - words of warning from the Crozet Island Simuliidae (Diptera). Cimbebasia 19: $157-164$.

Craig DA, Currie DC, Vernon P. 2003. Crozetia Davies (Diptera: Simuliidae): redescription of Cr. crozetensis, Cr. seg$u y i$, number of larval instars, phylogenetic relationships and historical biogeography. Zootaxa 259: 1-39.

Dalziel IWD, Dott Jr RH, Winn Jr RD, Bruhn RL. 1975. Tectonic Relations of South Georgia Island to the Southernmost Andes. Geological Society of America Bulletin 86: 1034-1040.

Dalziel IWD, Lawver LA, Pearce JA, Barker PF, Hastie AR, Barfod DN, Schenke H-W, Davis MB. 2013. A potential barrier to deep Antarctic circumpolar flow until the late Miocene? Geology 41(9): 947-950.

Dastych H. 1999a. A new species of the genus Mopsechiniscus Du Bois-Reymond Marcus, 1944 (Tardigrada) from the Venuezela Andes. Acta Biologica Benrodis 10: 91-101.

Dastych H. 1999b. Redescription of the Sub-Antarctic tardigrade Mopsechiniscus imberbis (Richters, 1908) (Tardigrada). Mitteilungen aus dem Hamburgischen Zoologischen Museum und Institut 96: 21-35.

Dastych H. 1999c. Mopsechiniscus frenoti sp. n., a new waterbear (Tardigrada) from Îles Crozet, the Sub-Antarctic. Entomologische Mitteilungen aus dem Zoologischen Museum Hamburg 13: 49-57.

Dastych H. 2000. Redescription of the Neotropical tardigrade Mopsechiniscus granulosus Mihelčič, 1967 (Tardigrada). Mitteilungen aus dem Hamburgischen Zoologischen Museum und Institut 97: 45-57.

Dastych H. 2001. Notes on the revision of the genus Mopsechiniscus (Tardigrada). Zoologischer Anzeiger 240: 299-308.

Dastych H, Moscal AM. 1992. Mopsechiniscus tasmanicus sp. n., a new semiterrestrial Tardigrada. Entomol. Entomologische Mitteilungen aus dem Zoologischen Museum Hamburg 10: 221-228.

Drummond AJ, Rambaut A. 2007. BEAST: Bayesian evolutionary analysis by sampling trees. BMC Evolutionary Biology 7: 214.

Du Bois-Reymond Marcus E. 1944. Comunicationes zoologicas del museo de Historia Natural de Montevideo. Comunicaciones Zoológicas del Museo de Historia Natural de Montevideo 13: 1-19.

Edgar RC. 2004. MUSCLE: multiple sequence alignment with high accuracy and high throughput. Nucleic Acids Research 32: 1792-1797.

Fraser CI, Nikula R, Ruzzante DE, Waters JM. 2012. Poleward bound: biological impacts of Southern Hemisphere glaciations. Trends in Ecology \& Evolution 27: 462-471.

Giret A, Weis D, Zhou X, Cottin JY, Tourpin S. 2003. Géologie des îles Crozet. Géologue 137: 15-23.

Grigarick AA, Schuster RO, Nelson DR. 1983. Heterotardigrada of Venezuela (Tardigrada). Pan-Pacific Entomologist 59: 64-77.

Guidetti R, Altiero T, Rebecchi L. 2011. On dormancy strategies in tardigrades. Journal of Insect Physiology 57: 567-576. 
Guidetti R, Rebecchi L, Cesari M, McInnes SJ. 2014. Mopsechiniscus franciscae a new species of a rare genus of Tardigrada from continental Antarctica. Polar Biolology 37: 1221-1233.

Guidetti R, Rebecchi L, Bertolani R, Jönsson KI, Kristensen RM, Cesari M. 2016. Morphological and molecular analyses on Richtersius (Eutardigrada) diversity reveal its new systematic position and lead to the establishment of a new genus and a new family within Macrobiotoidea. Zoological Journal of the Linnean Society 178: 834-845.

Guil N, Giribet G. 2012. A comprehensive molecular phylogeny of tardigrades - adding genes and taxa to a poorly resolved phylum-level phylogeny. Cladistics 28: 21-49.

Guil N, Jørgensen A, Giribet G, Kristensen RM. 2013. Congruence between molecular phylogeny and cuticular design in Echiniscoidea (Tardigrada, Heterotardigrada). Zoological Journal of the Linnean Society 169: 713-736.

Jørgensen A, Møbjerg N, Kristensen RM. 2007. A molecular study of the tardigrade Echiniscus testudo (Echiniscidae) reveals low DNA sequence diversity over a large geographical area. Journal of Limnology 66: 77-83.

Jørgensen A, Møbjerg N, Kristensen RM. 2011. Phylogeny and evolution of the Echiniscidae (Echiniscoidea, Tardigrada) an investigation of the congruence between molecules and morphology. Journal of Zoological Systematics and Evolutionary Research 49: 6-16.

Kaczmarek Ł, Michalczyk Ł, McInnes SJ. 2014. Annotated zoogeography of non-marine Tardigrada. Part II: South America. Zootaxa 3923: 1-107.

Kass RE, Raftery AE. 1995. Bayes factors. Journal of the American Statistical Association 90(430): 773-795.

Kristensen RM. 1987. Generic revision of the Echiniscidae (Heterotardigrada), with a discussion on the origin of the family. Pp. 261-335 in Bertolani R. ed, Biology of Tardigrades. Selected Symposia and Monographs U.Z.I. 1. Modena: Mucchi.

Lawver LA, Gahagan LM. 2003. Evolution of Cenozoic seaways in the circum-Antarctic region. Palaeogeography, Palaeoclimatology, Palaeoecology 198: 11-37.

Livermore R, Nankivell A, Eagles G, Morris P. 2005. Paleogene opening of Drake Passage. Earth Planetary Science Letters 236: 459-470.

Marshall DJ, Pugh PJA. 1996. Origin of the inland Acari of Continental Antarctica, with particular reference to Dronning Maud Land. Zoological Journal of Linnean Society 118: 101-118.

McInnes SJ. 1994. Zoogeographic distribution of terrestrial/ freshwater tardigrades from current literature. Journal of Natural History 28(2): 257-352.

McInnes SJ, Pugh PJA. 1998. Biogeography of limno-terrestrial Tardigrada, with particular reference to the Antarctic fauna. Journal of Biogeography 25: 31-36.

Mihelčič F. 1967. Ein Beitrag zur Kenntnis der Tardigrades Argentiniens. Verhandlungen der Zoologisch-Botanischen Gesellschaft in Wien 107: 43-56.

Mihelčič F. 1971/72. Ein weiterer Beitrag zur Kenntnis der Tardigraden Argentiniens. Verhandlungen der ZoologischBotanischen Gesellschaft in Wien 111-112: 47-52.

Møbjerg N, Halberg KA, Jørgensen A, Persson D, Bjørn M, Ramløv H, Kristensen RM. 2011. Survival in extreme environments-on the current knowledge of adaptations in tardigrades. Acta Physiologica 202: 409-420.
Ottesen PS, Meier T. 1990. Tardigrada from the Husvik area, South Georgia, sub-Antarctic. Polar Research 8(2): 291-294.

Pilato G, Binda MG. 2001. Biogeography and limno-terrestrial tardigrades: are they truly incompatible binomials? Zoologischer Anzeiger 240: 511-516.

Pugh PJA. 2004. Biogeography of spiders (Araneae: Arachnida) on the islands of the Southern Ocean. Journal of Natural History 38: 1461-1487.

Pugh PJA, Convey P. 2000. Scotia Arc Acari: antiquity and origin. Zoological Journal of the Linnean Society 130: 309-328.

Pugh PJA, Convey P. 2008. Surviving out in the cold: Antarctic endemic invertebrates and their refugia. Journal of Biogeography 35: 2176-2186.

Pugh PJA, Scott B. 2002. Biodiversity and biogeography of non-marine Mollusca on the islands of the Southern Ocean. Journal of Natural History 36: 927-952.

Ramazzotti G. 1962. Tardigradi del Cile, con descrizione di quattro nuove specie e di una nuova varietà. Atti della Società Italiana di Scienze Naturali e del Museo Civico di Storia Naturale di Milano 101: 275-287.

Richters F. 1907. 9. Antarktische Tardigraden. Zoologische Anzeigher 31: 915-917.

Richters F. 1920. Moosbewohner. Wissenschaftliche Ergebnisse der Schwedischen Südpolar-Expedition. 1901-1903. Stockholm 6, 1-16.

Regier JC, Shultz JW, Kambic RE, Nelson DR. 2004. Robust support for tardigrades clades and their ages from three protein-coding nuclear genes. Invertebrate Biology 123: 93-100.

Rossi GC, Claps MC. 1989. Tardigrados de la Argentina. V. Revista de la Sociedad Entomologica Argentina 47: 133-142.

Rossi G, Claps M, Ardohain D. 2009. Tardigrades from northwestern Patagonia (Neuquén Province, Argentina) with the description of three new species. Zootaxa 2095: 21-36.

Roszkowska M, Stec D, Ciobanu DA, Kaczmarek Ł. 2016. Tardigrades from Nahuel Huapi National Park (Argentina, South America) with descriptions of two new Macrobiotidae species. Zootaxa 4105(3): 243-260.

Rota-Stabelli O, Daley A, Pisani D. 2013. Molecular Timetrees Reveal a Cambrian Colonization of Land and a New Scenario for Ecdysozoan Evolution. Current Biology 23: 392398.

Scher HD, Martin EE. 2006. Timing and Climatic Consequences of the Opening of Drake Passage. Science 312: 428-430.

Schlich R, Simpson ESW, Vallier TL. 1974. Regional aspects of deep sea drilling in the western Indian Ocean, leg 25. Pp. 743-759 in: Simpson ESW, Schlich R, et al., eds, Initial Reports of the Deep Sea Drilling Project. DSDP Volume XXV. Washington D.C.: U.S. Government Printing Office.

Stevens MI, Greenslade P, Hogg ID, Sunnucks P. 2006. Southern Hemisphere Springtails: Could Any Have Survived Glaciation of Antarctica? Molecular Biology and Evolution 23: 874-882.

Stevens MI, Hogg ID. 2003. Long-term isolation and recent range expansion from glacial refugia revealed for the endemic springtail Gomphiocephalus hodgsoni from Victoria Land, Antarctica. Molecular Ecology 12: 2357-2369.

Stevens MI, Hogg ID. 2006. Contrasting levels of mitochondrial DNA variability between mites (Penthalodidae) and springtails (Hypogastruridae) from the Trans-Antarctic Mountains suggest long-term effects of glaciation and life 
history on substitution rates, and speciation processes. Soil Biology and Biochemistry 38: 3171-3180.

Suchard MA, Weiss RE, Sinsheimer JS. 2001. Bayesian selection of continuous-time Markov chain evolutionary models. Molecular Ecology and Evolution 18(6): 1001-1013.

Thomson MRA. 2004. Geological and palaeoenvironmental history of the Scotia Sea region as a basis for biological interpretation. Deep Sea Research Part II: Topical Studies in Oceanography 51: 1467-1487.

Velasco-Castrillón A, Gibson JA, Stevens MI. 2014. A review of current Antarctic limno-terrestrial microfauna. Polar Biology 37(10): 1517-1531.

Vernon P, Caron F, Davies L. 1999. Annual activity of two endemic beetles (Carabidae) at the edge between fell-field and moorland on a sub-Antarctic island. European Journal of Soil Biology 35: 39-43.

Vicente F, Fontoura P, Cesari M, Rebecchi L, Guidetti R, Serrano A, Bertolani R. 2013. Integrative taxonomy allows the identification of synonymous species and the erection of a new genus of Echiniscidae (Tardigrada, Heterotardigrada). Zootaxa 3613: 557-572.

Vyverman W, Verleyen E, Wilmotte A, Hodgson DA, Willems A, Peeters K, Van de Vijver B, De Wever A, Leliaert F, Sabbe K. 2010. Evidence for widespread endemism among Antarctic micro-organisms. Polar Science 4: 103-113.

Wełnicz W, Grohme MA, Kaczmarek Ł, Schill RO, Frohme M. 2011. Anhydrobiosis in tardigrades-the last decade. Journal of Insect Physiology 57: 577-583.

Zhang ML. 2011. A cladistic scenario of Southern Pacific biogeographical history based on Nothofagus dispersal and vicariance analysis. Journal of Arid Land 3: 104-113.

Received: 21 June 2016

Revised and accepted: 2 March 2017

Published online: 31 May 2017

Editor: Alessandro Minelli 